\title{
BRIEFING
}

\section{Back on Track? Somaliland after its 2017 Presidential Election}

\author{
Scott Pegg and Michael Walls*
}

On 13 December 2017, Somaliland's fifth president, Musa Bihi Abdi was inaugurated. Bihi ran as candidate for the ruling Kulmiye party after the incumbent president, Ahmed Mohamed Mohamoud 'Silanyo', decided not to seek re-election. Article Nine of Somaliland's Constitution allows for only three political parties, and Bihi defeated Abdirahman Mohamed Abdullahi 'Irro' of Waddani party, and Faisal Ali 'Warabe' of the For Justice and Development (UCID) party. The race was widely expected to be a close contest between Kulmiye and Waddani, with UCID playing a minor role. Ultimately, though, Bihi secured an outright majority with 55.1 percent (305,909 votes) to Irro's 40.7 percent $(226,092$ votes) and Warabe's 4.2 percent (23,141 votes). In securing more votes than the other two parties combined, Kulmiye's margin of victory of 79,817 votes exceeded most expectations. Domestic and international observers found minor problems with the election but generally hailed its peaceful and orderly nature. This briefing reflects on the election and campaign, and assesses the key challenges facing the new administration. President Bihi's daunting 'todo' list includes determining the future of Somaliland's iris-based voter registration system, enabling badly delayed legislative elections, reevaluating Somaliland's increasingly

\footnotetext{
* Scott Pegg (smpegg@iupui.edu) is Professor and Chair of the Department of Political Science at Indiana University Purdue University Indianapolis (IUPUI). He served as an international election observer for Somaliland's 2017 presidential election. Michael Walls (m.walls@ucl.ac.uk) is a Senior Lecturer and Course Director for Development Administration and Planning at the Development Planning Unit, University College London. He was Chief Observer for Somaliland's 2017 presidential election, and has also helped coordinate observations in 2005, 2010 and 2012.
} 
dysfunctional hybrid mix of traditional and modern governance, developing potential oil reserves and deciding whether to resume talks with Mogadishu.

A former British protectorate, Somaliland reasserted its sovereignty by declaring independence from Somalia in 1991. Somaliland's separate colonial status (namely its five days of sovereign independence in June 1960 before uniting with the former Italian colony of Somalia) coupled with questions over the legality of its union with Somalia and the brutal destruction meted out by Siad Barre's regime in the war to depose him, make it possible for Somaliland to present its case as the dissolution of a failed union rather than as secession. These factors, accompanied by a commitment to respect colonial borders, give Somaliland a uniquely powerful argument for the recognition of its sovereignty. ${ }^{1}$ A 2005 African Union fact-finding mission found that all of this 'makes Somaliland's search for recognition historically unique and self-justified in African political history' and held that recognizing Somaliland would not open up a 'Pandora's box' of other secessionist claims. ${ }^{2}$ Yet, although peaceful since $1997,{ }^{3}$ and having made considerable progress toward economic recovery and electoral democracy, 26 years after declaring independence, Somaliland remains a de facto state: an entity that controls territory, provides governance, receives popular support, persists over time and yet remains unrecognized by other sovereign states. ${ }^{4}$

\footnotetext{
${ }^{1}$ Mark Bradbury, Becoming Somaliland (Indiana University Press, Bloomington, 2008); Matt Bryden, 'Statewithin-a-failed state: Somaliland and the challenge of international recognition', in Paul Kingston and Ian S. Spears (eds), States within states: Incipient political entities in the post-cold war era (Palgrave Macmillan, New York, 2004), pp. 167-188.

${ }^{2}$ African Union, 'Resume: AU Fact-Finding Mission to Somaliland (30 April to 4 May 2005)' (African Union, Addis Ababa, 2005), paragraph 8.

${ }^{3}$ Michael Walls, 'The emergence of a Somali state: Building peace from civil war in Somaliland', African Affairs, 108, 432 (2009), pp. 371-389.

${ }^{4}$ Scott Pegg, International society and the de facto state (Ashgate, Aldershot, 1998).
} 


\section{Democracy in Somaliland}

The 2017 vote was Somaliland's third direct presidential election (following earlier polls in 2003 and 2010) and its sixth direct election overall (including local council elections in 2002 and 2012 and parliamentary elections in 2005). ${ }^{5}$ International election observers have monitored elections and generally found them to be well run and credible with the partial exception of the 2012 local council elections when the lack of a voter registry and the 'ease with which indelible ink was removed may have permitted a substantial number of voters to cast multiple ballots, potentially reducing the integrity of results' ${ }^{6}$

Somaliland's democracy juxtaposes striking successes with recurrent and persistent problems. Its biggest success by far is in institutionalizing the regular turnover of its presidents. In their work on the institutionalization of political power in sub-Saharan Africa, Posner and Young identify five ways in which leaders can leave office, grouped into two broad categories: 'those in which leaders left power through regular means (which include natural death, voluntary resignation, or losing an election) and those in which leaders were removed by irregular means (coup or violent overthrow or assassination)' ${ }^{7}$ Somaliland's first four presidents - Abdirahman Ahmed Ali 'Tuur' (1991 - 1993, losing an election among clan elders), Mohamed Ibrahim Egal (1993 - 2002, natural death), Dahir Riyale Kahin (2002 - 2010, losing a popular election) and Ahmed Mohamed Mohamoud 'Silanyo' (2010 - 2017, voluntary resignation/not seeking reelection) - have all left office through regular means. To the extent that the regular turnover of leaders 'marks the most important step toward

\footnotetext{
${ }^{5}$ Somaliland also held a referendum on its constitution in 2001.

${ }^{6}$ Michael Walls and Steve Kibble, Swerves on the road: Report by international election observers on the 2012 local elections in Somaliland (Progressio, London, 2013), p. 21.

${ }^{7}$ Daniel N. Posner and Daniel J. Young, 'The institutionalization of political power in Africa', Journal of Democracy, 18, 3 (2007), p. 128.
} 
restraining executive power and institutionalizing political authority more broadly, ${ }^{8}$ Somaliland is a consolidated democracy.

Somaliland's democracy has also survived several shocks or crises including the unexpected death of President Egal in 2002, his replacement by a vice-president from a minority clan in accordance with Somaliland's constitution, an incredibly close 2003 presidential election with an initial margin of victory of 80 votes whose result the loser accepted, two opposition parties winning control of Somaliland's parliament in 2005, repeated delays to a presidential election originally scheduled for 2008 but not held until 2010 and the implosion of the country's previous ruling party, the United Peoples' Democratic Party (UDUB), after its defeat in those elections.

Somaliland's innovative 'hybrid' mix of traditional, clan-based structures (now institutionalized in the Guurti or upper house of parliament) and modern state institutions has been widely praised, with Richards going so far as to argue that, for Somaliland, 'institutionalized traditional authority is not a sacrifice of acceptable statehood, but rather a necessity for acceptable statehood to be achieved in the emerging state'. ${ }^{9}$

Yet, Caspersen's conclusion that 'unrecognized states often run out of steam and find themselves in a seemingly perpetual transition; they make steps towards democratization but reach a plateau fairly early on and may even experience democratic setbacks' is by no means irrelevant to Somaliland. ${ }^{10}$ As is the case with other Eurasian de facto states like Abkhazia, Nagorno Karabakh and Transnistria, Somaliland features a presidential system 'in which the

\footnotetext{
${ }^{8}$ Ibid, p. 130.

${ }^{9}$ Rebecca Richards, Understanding statebuilding: Traditional governance and the modern state in Somaliland (Ashgate, Farnham, 2014), p. 150. See also Michael Walls and Steve Kibble, 'Beyond polarity: Negotiating a hybrid state in Somaliland', Africa Spectrum, 45, 1 (2010), pp. 31-56.

${ }^{10}$ Nina Caspersen, Unrecognized states: The struggle for sovereignty in the modern international system (Polity, Cambridge, 2012), p. 98.
} 
executive eclipses both legislative and judicial arms of government'. ${ }^{11}$ The great excitement initially felt in 2005 when two opposition parties won control of Somaliland's parliament quickly dissipated because 'When the opposition won... they realized they had nothing'. ${ }^{12}$

Somaliland's regular turnover of its presidents is also tempered by repeated delays to its elections. Correctly fearing his own loss of power, President Riyale engineered a series of delays that prevented elections, originally scheduled for 2008, from being held until 2010 . Even though he was in poor health and not seeking reelection, President Silanyo's preference for holding elections as scheduled in 2015 could not prevent them from being delayed until 2017. The situation is even worse with the legislative branch. Upper house or Guurti members ostensibly serve six-year terms but have not been elected or selected since 1997. The Guurti's repeated self-extensions and the tendency to replace deceased members with immediate family has greatly undermined public confidence in the institution. ${ }^{13}$ Presidential dominance is exacerbated by the fact that lower house MPs, with a constitutionally-mandated term of five years, have not faced election since 2005 .

Somaliland's previously lauded system of traditional and modern governance is increasingly dysfunctional. While most observers credit clan elders and their subsequent institutionalization as the upper house of parliament with helping to maintain peace and enable Somaliland's early development, there are increasing fears that 'the basis for the stability necessary to create the state could also be the basis for instability if the relationship between the traditional and the modern becomes unbalanced'. ${ }^{14}$ Ken Menkhaus highlights the

\footnotetext{
${ }^{11}$ Donnacha Ó Beacháin, Giorgio Comai and Ann Tsurtsumia-Zurabashvili, 'The secret lives of unrecognized states: Internal dynamics, external relations, and counter-recognition strategies', Small Wars and Insurgencies, 27, 3 (2016), p. 445.

12 Personal interview, Mohammed Hassan Ibrahim, Hargeisa, 26 July 2010.

${ }^{13}$ Markus Virgil Hoehne, 'Limits of hybrid political orders: The case of Somaliland', Journal of Eastern African Studies, 7, 2 (2013), pp. 199-217; Richards, Understanding statebuilding.

${ }^{14}$ Richards, Understanding statebuilding, p. 173. See also Ken Menkhaus, 'State failure, state building, and prospects for a "functional failed state" in Somalia', The Annals of the American Academy of Political and Social Science, 656, 1 (2014), p. 170.
} 
negative economic consequences of hybrid or informal governance and argues that 'evidence is mounting that... the country must move toward more robust institutions and formal rule of law if it is to attract and regulate new levels of private sector investment' ${ }^{15}$ More generally, Hoehne argues that the Guurti has now been effectively coopted into the executive and no longer serves as a check on presidential power. Somaliland, in his view, finds itself today with 'not only an imbalanced but a 'crippled' hybrid order that advances neither effective democracy nor strong traditional governance, but undermines both the Western-oriented state and the home-grown traditional system'. ${ }^{16}$

\section{Pre-election delays and voter registration}

The November 2017 presidential election was originally scheduled for June 2015. In March 2015, Somaliland's National Electoral Commission (NEC) requested a nine-month delay, principally to complete voter registration. A series of debates and controversies ultimately intertwined to extend the NEC's proposed nine-month delay to nearly 2.5 years. Although President Silanyo had announced he was not seeking re-election and wanted to step down, Kulmiye party members were divided between those who thought an earlier election gave them an advantage over Waddani, which only became a political party after the 2012 local council elections, and those who wanted to remain in office for as long as possible. One major controversy centered on whether presidential and parliamentary elections should be combined or held separately. President Silanyo was a strong proponent of separating them and holding presidential elections first while Somaliland's western supporters argued strongly for holding presidential and parliamentary elections simultaneously. Concerns that

\footnotetext{
${ }^{15}$ Menkhaus, 'State failure, state building', p. 170. See also World Bank, Somaliland's private sector at a crossroads: Political economy and policy choices for prosperity and job creation (World Bank, Washington, DC, 2016), pp. 78-84.

${ }^{16}$ Hoehne, 'Limits of hybrid political orders', p. 213.
} 
significant population displacement caused by the severe drought in Somaliland's eastern regions would delay voter registration and, later, the distribution of voter cards also featured prominently in the rationales advanced for delaying the election. ${ }^{17}$

The NEC's initial request for a nine-month delay was transformed by the Guurti into a controversial two-year extension of President Silanyo's term until March 2017. Under Article 83 of Somaliland's constitution, the Guurti can extend the president's term if elections cannot be held 'because of security considerations', but it was not clear that those conditions existed. In January 2017, two months before the scheduled March 2017 elections, the three political parties agreed to delay the election for a further six months due to the ongoing drought in the east which complicated voter card distribution. The Guurti added two more months to this agreement and mandated a separate and distinct process for parliamentary elections. Ultimately, the NEC established 13 November 2017 as the new date for the presidential elections. Lower house parliamentary elections are now scheduled for 29 April 2019. ${ }^{18}$

Somaliland's initial attempt to develop a secure voter register before the 2010 presidential elections was mired in controversy. Although the resultant register was employed in those elections, it "was by then so tainted by errors and problems that it was abandoned not long afterwards'. ${ }^{19}$ The lack of a voter registry and the ease by which indelible ink was removed meant that 'successful attempts at multiple voting occurred at very significant levels' during the 2012 local elections. ${ }^{20}$ To address these problems, Somaliland adopted sub-

\footnotetext{
${ }^{17}$ Omar S. Mahmood and Mohamed Farah, High stakes for Somaliland's presidential elections (Institute for Security Studies, Addis Ababa and Academy for Peace and Development, Hargeisa, 2017), pp. 3-5; Statement by international partners to Somaliland on the postponement of the presidential and local elections, 26 January 2017 ,

$<$ https://eeas.europa.eu/sites/eeas/files/final._statement_by the international_partners_to_somaliland._2017.01. 26.pdf $>$ (14 December 2017).

${ }^{18}$ Mahmood and Farah, High stakes, p. 4.

${ }^{19}$ Marie-Luise Schueller and Michael Walls, Report by international observers on the 2016 voter registration process (Progressio, London, 2017), p. 5.

${ }^{20}$ Walls and Kibble, Swerves on the road, p. 32. See also Mahmood and Farah, High stakes, p. 5.
} 
Saharan Africa's first iris-based biometric voter registration system. Field tests were conducted in 2014 and voter registration ran from January - September 2016 in 21 of the 23 districts across Somaliland's six regions. International observers found a generally advanced level of understanding of the process, a high proportion of voters who were able to get clean iris scans on both eyes and an average start-to-finish completion time of ten minutes for the registration process. ${ }^{21} 873,331$ voters successfully completed registration. That number surprised some, who had expected more, perhaps because the widely discredited 2009 voter register included, in its final form, 1,069,914 registered voters. ${ }^{22}$

The distribution of voter cards started in shifts in April 2017 in the Awdal and Saahil regions and concluded in September 2017 in Sool and Sanaag. Ultimately, 704,089 voters collected their cards, with the collection rate ranging from 69.76 percent in Awdal to 94.26 percent in Sanaag, and a national average of 80.62 percent. $^{23}$ The 169,242 registrants who did not collect their cards were ineligible to vote.

There is widespread agreement that the iris-based biometric voter registration worked well and was generally embraced by Somaliland's electorate. The fact that voters had to vote in a specific polling station and that officials had printouts of each voter's registration card and could thus match card numbers and faces, dramatically reduced the problem of multiple voting seen in 2012 .

There are, however, several concerns with the voter registration system. First, all 873,331 voters registered more than one year before the actual poll, and some registered almost two years in advance of election day, yet there were no provisions for late registration or for replacement of lost or stolen cards. Also, while the iris-based biometric registration

\footnotetext{
${ }^{21}$ Schueller and Walls, Report by international observers, pp. 16-17.

${ }^{22}$ Michael Walls and Steve Kibble, Change and continuity: Report by international election observers on the June 2010 presidential elections in Somaliland (Progressio, London, 2011), p. 35.

${ }^{23}$ Mahmood and Farah, High stakes, p. 6.
} 
system is extremely good at preventing multiple registrations, it cannot verify age so, in the absence of a national birth registry, underage voters can still register if an accredited clan elder (caaquil) vouches for them. International observers saw many examples of voters who appeared to be under Somaliland's voting age of 16. This is not a fault of the iris-based system, but it illustrates some of the limits to it. Finally, there are no plans yet for updating the system to ensure newly eligible voters or those who missed out in 2017 can be included.

\section{Election campaign: Historic debate, heated rhetoric, limited policy focus}

Although the official campaign did not start until 21 October 2017, it was preceded two days earlier by a historic milestone when all three presidential candidates gathered at the Maan Soor Hotel in Hargeisa for Somaliland's first-ever televised presidential debate. In fact, the debate was only the seventh presidential debate anywhere in sub-Saharan Africa since 1960, and was shown live on Facebook and on nine Somali-language television channels. It attracted an estimated 8-9,000,000 viewers across the Horn of Africa. Remarkably, the debate was organized by a handful of Somaliland youth, most in their 20s, and members of the nongovernmental organization, the Inspire Group. The success of the event has created a widespread expectation that all subsequent presidential elections in Somaliland will feature similar debates. The steady performance of Musa Bihi Abdi, who was not previously viewed as a natural politician, was widely seen as boosting his campaign, although many considered the UCID leader, 'Warabe', the clear winner.

Somaliland's official campaign season ran for 21 days from 21 October -10 November with each party allocated seven days for exclusive campaigning on rotation. The designation of separate campaign days for each party is intended to minimize the potential for clashes between rival supporters. While this approach largely worked as intended, things nevertheless became heated, particularly in the second week. Social media played a 
dramatically larger role than previously. In many ways, this was a positive development, with \#SomalilandDebates and \#SomalilandVotes serving as valuable conduits of information and individual Somalilanders like Rooble Mohamed, whose@Rooble2009 Twitter account has more than 16,000 followers, performing a similar role. Yet Somaliland also saw a semiepidemic of fake news, including assorted rumors that key party officials were negotiating to desert one major party for the other, and ad hominem character attacks on party officials or ministers.

The candidates' own rhetoric also became heated at times, with 'Warabe' (presumably metaphorically) suggesting that anyone who traveled to Somalia should be put to death. Causing far more controversy, Bihi accused Waddani candidate 'Irro' of being a closet Somali unionist, with 'Irro' hitting back with the accusation that Bihi is a war criminal. 'Irro' also had his house vandalized. Fortunately, in typical Somaliland fashion, things calmed down dramatically in the third week of the campaign after various formal and informal interventions by respected individuals, aided by President Silanyo's forceful condemnation of the attack on Irro's house. One novel development was the decision by political parties to devote some of their campaign time to charity events, helping poor or disabled citizens. These interventions dramatically reduced tensions and helped put Somaliland back on track for a peaceful election.

One disappointing aspect of the campaign was how little attention was devoted to policy. Supporters of each major party were quick to emphasize the passion behind their disagreements, but struggled when asked to elaborate on specific issues or policies on which they differed. In some ways, UCID, with its argument for more state intervention in the economy and its promise to devote 15 percent of the government's budget to health care boasted a clearer policy platform than either of the others. Perhaps the sharpest difference 
between Kulmiye and Waddani centered around the government's deals with DP World ${ }^{24}$ to renovate Berbera's port and with the United Arab Emirates to establish a military base in Berbera. Kulmiye's campaign promised continuity, while Waddani's campaign emphasized the deals' problems and promised to renegotiate both.

The election and its immediate aftermath: Peaceful poll but difficult post-vote period Somaliland had 1,642 polling stations operating for election day. Typically, polling stations were staffed by four NEC employees, often university students, who were deployed outside their home regions to minimize the potential for clan connections to compromise impartiality. In the urban centers, it was not unusual to find polling stations staffed entirely by women. In the rural areas, all-male polling staff was the norm. In addition to officials, most polling stations had observers present from the three political parties. In most cases, the International Election Observation Mission witnessed these ‘party agents' working collaboratively and amicably. The Somaliland Non-State Actors Forum (SONSAF) deployed 620 domestic observers, each remaining in one polling station all day and collectively covering about 38 percent of all polling stations. The International Election Observation Mission deployed 60 observers from 27 different countries in 30 teams of two persons each across all six of Somaliland's regions. On average, international observers spent 20-30 minutes at each polling station and covered about 350 polling stations or just over 21 percent of the total. Somaliland police officers were deployed outside all polling stations but were not supposed to enter them. In most cases, they maintained a discreet and professional presence and did not interfere with the conduct of the election.

\footnotetext{
${ }^{24}$ DP World is a Dubai-based company which runs 78 marine and inland terminals in 40 countries across six continents and which handled around 64 million TEU (twenty-foot equivalent units) in 2016.
} 
By almost all accounts, the election was peaceful, festive and orderly. ${ }^{25}$ Hundreds of voters were queued outside polling stations hours before they opened at 7:00 AM. In total, 555,142 voters cast ballots, a turnout of 78.85 percent of those who picked up their registration cards and 63.57 percent of all those who registered to vote. Domestic and international observers noted minor irregularities in places but nothing that affected the overall integrity of the election. In addition to the concern about potentially underage voters, probably the most consistent departure from international electoral norms concerned the secrecy of the ballot. Many Somalilanders do not feel a need to keep their preferences secret and disabled or illiterate voters would often enter a polling station and loudly proclaim the party for which they wished to vote, requesting assistance to do so. In some polling stations, officials would try to explain how to vote for that party, while asking the voter to mark the ballot themselves. In other polling stations, officials would mark the ballot for the voter in accordance with his or her wish. In all such cases, the ballot would be shown to any domestic, international or political party observers present so they could see that the voter's clearly expressed preference was honored. While the secrecy of the ballot was not maintained, voters' wishes were respected. This is more a reflection of the openness of Somaliland culture or society than it is a malign violation of international norms. ${ }^{26}$

At about 4:00 PM on the day of the election, Somaliland's government blocked all access to social media sites including Facebook, Twitter and WhatsApp. This controversial ban was justified as a measure to prevent the circulation of unsubstantiated accusations of fraud and unfounded rumors as to the victor and remained in place until 17 November.

\footnotetext{
${ }^{25}$ International Election Observation Mission, 'International observers of Somaliland's presidential election congratulate the Somaliland people on a peaceful poll', 14 November 2017, <http://somalilandfocus-orguk.stackstaging.com/wp-content/uploads/2017/11/EOM-Press-Release-6.pdf $>$ (5 January 2018); 'Somaliland: International partners congratulate the people of Somaliland on their peaceful and responsible voting for a new president', 21 November 2017, <http://www.horndiplomat.com/2017/11/21/somalilandinternational-partnerscongratulate-the-people-of-somaliland-on-their-peaceful-and-responsible-voting-for-a-new-president $/>(5$ January 2018).

${ }^{26}$ Walls and Kibble, Swerves on the road, p. 23; Walls and Kibble, Change and continuity, pp. 27-28.
} 
Whatever one's views on this temporary ban, it did not prevent election rumors from circulating or preserve the peaceful atmosphere seen on election day. After Waddani officials alleged electoral irregularities in Berbera and Gabiley, demonstrations erupted in Burao and Hargeisa on 16 November, leaving three people dead and nine injured. ${ }^{27}$ Calm was quickly restored after interventions by President Silanyo and Waddani's Irro, but the violence seemed utterly unnecessary after the peaceful and orderly conduct of the election. Waddani repeated allegations of fraud, vote rigging, fake ballot papers and other irregularities and ceased cooperation with the NEC a few days after the election, but ultimately, Irro conceded defeat because he did not want his 'desire to hold this post [to] destroy my country and shed my people's blood'. However, he still maintained that there were 'irregularities' and that the NEC had 'declared false results'. ${ }^{28}$

\section{Future challenges: Legislative elections, oil and port development, international status}

When asked what he would view as an early mark of success for the new government, Somaliland's former finance minister and former foreign minister Abdillahi Duale (who campaigned for Musa Bihi Abdi in this election) immediately replied that he would look for the appointment of a smaller and leaner cabinet of 12-15 ministers, all of whom were selected based on their competence rather than their clan affiliation. ${ }^{29}$ President-elect Bihi similarly promised a smaller cabinet of 15 ministers. ${ }^{30}$ This was largely in response to a widespread

\footnotetext{
27 'Somaliland: Human Rights Defenders Group expresses deep concern over the deaths of civilians at postelection disturbances', Somaliland Informer, 19 November 2017,

$<$ http://www.somalilandinformer.com/somaliland/somaliland-human-rights-defenders-group-expresses-deepconcern-over-the-deaths-of-civilians-at-post-election-disturbances/> (15 December 2017).

28 'Somaliland presidential candidate Abdirahman Irro concedes defeat,' Hiiraan Online, 22 November 2017, $<$ https://www.hiiraan.com/news4/2017/Nov/145371/somaliland_presidential_candidate_abirahman_irro_conced es_defeat.aspx $>$ (15 December 2017).

${ }^{29}$ Personal interview, Abdillahi M. Duale, Hargeisa, 15 November 2017.

30 'Somaliland: President-elect promises lean cabinet', Somaliland Informer, 29 November 2017, $<$ http://www.somalilandinformer.com/somaliland/somaliland-president-elect-promises-lean-cabinet/> $(16$ December 2017).
} 
feeling that the Silanyo Administration's cabinet had become unwieldy and bloated.

Ultimately, Bihi appointed 23 ministers and six deputy or assistant ministers. This arguably represents some progress but not as much as many Somalilanders hoped for.

The Bihi administration, in tandem with the NEC, faces three immediate electoral challenges. Decisions must be made soon about how the iris-based biometric voter registration system will be updated in the future to account for new voters coming of age and existing voters who have relocated or lost or failed to retrieve voter cards. The new administration must also identify a viable method for selecting or electing members of the Guurti or upper house of parliament. Guurti members who, under Article 58 of Somaliland's constitution, are supposed to serve six-year terms have not been elected or selected since 1997 and it is difficult to see how the dissatisfaction so vocally expressed with Somaliland's 'hybrid' mix of traditional and modern governance can be addressed in the absence of a regular and agreed method for Guurti membership election or selection. Unfortunately, as Jama notes, it is not an 'exaggeration to argue that almost all the members of the Guurti are against any change in their seats. Currently, they are enjoying indefinite and life time term'. ${ }^{31}$ Finally, the new administration desperately needs to keep lower house parliamentary elections, now scheduled for April 2019, on track..$^{32}$ If these elections are held on time, members of parliament will have served nine years beyond their constitutionally-mandated five-year terms. The sensitive issue here is agreeing upon a formula for reallocating parliamentary seats based on population changes. While the best option would be a national census, this would be both costly and controversial. Alternatively, Somaliland could decide to maintain the 2005 formula (which was based on population estimates in 1960) or it could

\footnotetext{
${ }^{31}$ Guleid Ahmed Jama, Parliamentary elections of Somaliland (Center for Policy Analysis, Hargeisa, 2016), p.

7, <http://centerforpolicy.net/parliamentary-elections-of-somaliland/> (9 August 2017).

32 These elections are scheduled to take place in tandem with local council polls.
} 
come up with some other negotiated compromise. ${ }^{33}$ Somaliland's political system will remain tilted toward the executive branch but each of the houses of parliament would be better able to serve as a check on executive dominance if their members were seen to have similarly legitimate mandates as the president.

Economically, Somaliland's new administration faces two major challenges and two potentially transformative opportunities. The first major challenge concerns Somaliland's dependence on remittances from its diaspora. There are no official figures on remittance volumes, but estimates range from US\$500-900 million per year, equivalent to 35-70 percent of Somaliland's gross domestic product (GDP). This makes Somaliland one of the world's most remittance-dependent economies. ${ }^{34}$ Questions abound as to how sustainable these flows are, particularly given that many of the people who left Somaliland in the 1980s or 1990s are now advanced in age. Somaliland's second major challenge is its heavy dependence on livestock exports in a drought-prone region where the adverse effects of global climate change are clearly visible. Nearly half the population depends entirely on livestock production for its livelihood and livestock production accounts for almost 30 percent of Somaliland's GDP and is its single largest export. ${ }^{35}$ As the World Bank notes, 'The sector's heavy dependence on the Saudi market for 80 percent of its exports reduces its options and bargaining positions'. ${ }^{36}$ Saudi Arabia imposed livestock export bans on Somaliland in 1998, in 2000 and again in 2016 and this ban remains in effect, although a limited and specific exception was made for the Hajj.

Somaliland's first potentially transformative opportunity concerns the redevelopment of the Berbera port and the larger Berbera-Hargeisa-Wajaale economic corridor. Ethiopia's

\footnotetext{
${ }^{33}$ Jama, Parliamentary elections, p. 6.

${ }^{34}$ World Bank, Somaliland's private sector at a crossroads, p. 45.

35 Ibid, p. 12.

36 Ibid.
} 
growing imports and its desire to have other options besides Djibouti offer significant potential upside for Somaliland. The success with which the Berbera port deal with DP World is implemented will greatly affect Somaliland's economic prospects. The second major opportunity or threat for Somaliland is oil production. Genel has recently completed extensive 2D seismic surveys and production could begin as early as 2019 or $2020 .{ }^{37}$ Oil could potentially generate hundreds of millions of dollars in revenues for Somaliland that could be used to build desperately needed infrastructure and alleviate poverty but, to date, Somaliland has done little to prepare legislatively or institutionally for the arrival of oil and a resource curse with or without commercially viable oil reserves remains a distinct possibility. ${ }^{38}$ This question will likely be answered during the Bihi Administration's first few years in office.

Finally, on the international front, Somaliland remains committed to seeking widespread international recognition of its proclaimed sovereignty but has made no progress in this regard. The Bihi Administration has an opportunity to direct more of its focus toward expanding Somaliland's 'engagement without recognition' with willing partners like Djibouti, Ethiopia, the UAE, the US and the UK. ${ }^{39}$ The other major international issue soon to confront the new administration will be whether and how to re-engage in talks with Somalia. There is widespread dissatisfaction in Somaliland with Turkey's role as a mediator in the previous talks and it is difficult to see the talks getting anywhere without new mediators. Somaliland will probably feel some pressure to seem cooperative, but it has

\footnotetext{
${ }^{37}$ Personal interviews, oil industry executive 1, Hargeisa, 11 November 2017 and oil industry executive 2, Hargeisa, 15 November 2017.

38 Jedrzej George Frynas, Geoffrey Wood and Timothy Hinks, 'The resource curse without natural resources: Expectations of resource booms and their impact', African Affairs, 116, 463 (2017), pp. 233-260.

${ }^{39}$ Eiki Berg and Scott Pegg, 'Scrutinizing a policy of “engagement without recognition": US requests for diplomatic actions with de facto states', Foreign Policy Analysis, 2018 forthcoming, http://dx.doi.org/10.1093/fpa/orw044; James Ker-Lindsay, 'Engagement without recognition: The limits of diplomatic interaction with contested states', International Affairs, 91, 2 (2015), pp. 267-285.
} 
gained little from earlier talks and will enter new ones with limited hopes for any substantive progress.

Somaliland deserves praise for its peaceful and successful presidential election. It has certainly suffered in recent years from having an aging president in declining health and will benefit from the fresh start of a new administration. The Bihi administration has been cautious since the inauguration in adopting a careful approach to assembling a cabinet and starting the new term, but they face considerable challenges if Somaliland is to be placed firmly on track to build on past progress. 